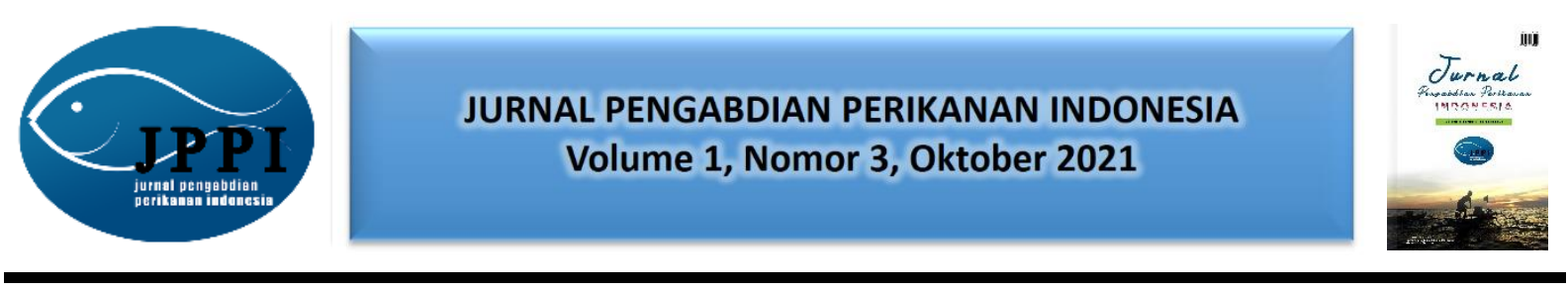

\title{
PENGEMBANGAN DESTINASI WISATA PANTAI NAPAK TILAS DESA LEMBAR SELATAN PADA MASA PANDEMIC COVID-19
}

\author{
Baiq Novi Suprianti ${ }^{1}$, Dina Istagina ${ }^{2}$, Siti Halimiaty ${ }^{3}$, Nurliah Buhari ${ }^{4 *}$ \\ ${ }^{1}$ Program Studi IImu Komunikasi Universitas Mataram, ${ }^{2}$ Program Studi Manajemen \\ Universitas Mataram, ${ }^{3}$ Program Studi Hubungan Internasional Universitas Mataram, \\ ${ }^{4}$ Program Studi Ilmu Kelautan Universitas Mataram \\ *Jalan Pendidikan No. 37, Kota Mataram, Provinsi Nusa Tenggara Barat \\ *Alamat korespondensi : nurliah.buhari@unram.ac.id
}

(Tanggal Submission: : 9 September 2021, Tanggal Accepted : 31 Oktober 2021)

\section{Keyword : Abstrak :}

Pengembangan Desa Lembar Selatan merupakan salah satu desa yang ada di Kecamatan Lembar, Wisata, Pantai Kabupaten Lombok Barat. Selain memiliki potensi wisata hutan mangrove juga Napak Tilas, memiliki potensi pantai yang dapat dikembangkan sebagai objek wisata Salah satu Lembar Selatan pantai tersebut adalah Pantai Napak Tilas. Pantai ini merupakan pantai berpasir dan mempunyai pemandangan yang unik. Tujuan pengabdian ini adalah melakukan pengembangan dan penataan destinasi wisata Pantai Napak Tilas. Kegiatan pengabdian ini dilakukan melalui program Kuliah Keja Nyata (KKN) selama 30 hari pada bulan Juni - Juli 2021. Kegiatan yang dilakukan dimulai dengan survei potensi wisata, penataan, dan pengembangan wisata. Survei dilakukan dengan cara observasi dan wawancara dengan pemerintah desa. Penataan dan pengembangan wisata dilakukan dengan membuat program kerja sesuai dengan permasalahan yang ditemukan saat survei. Seluruh program yang direncanakan untuk mengembangkan Pantai Napak Tilas seperti kegiatan bersih pantai, pembuatan sarana pendukung dan promosi melalui media sosial dapat terlaksana dengan baik berkat kerjasama antara mahasiswa, pemerintah desa, dan masyarakat. Pelaksanaan kegiatan mengikuti protokol Covid-19. Namun demikian, masalah sampah kiriman menjadi tantangan besar terbesar dalam pengelolaan Pantai Napak Tilas sehingga diperlukan kerjasama lebih lanjut antara masyarakat, pemerintah desa, dan pihak swasta untuk menanganinya. 
Panduan Sitasi (APPA $7^{\text {th }}$ edition) :

Suprianti, B. N., Istagina, D., Halimiaty, S., \& Buhari, N. (2021). Pengembangan Destinasi Wisata Pantai Napak Tilas Desa Lembar Selatan Pada Masa Pandemic Covid-19. Jurnal Pengabdian Perikanan Indonesia, 1 (3), 202-209. http://doi.org/ 10.29303/jppi.v1i3.390

\section{PENDAHULUAN}

Industri pariwisata memiliki berbagai peran penting dan kontribusi penting dalam berbagai aspek khususnya aspek ekonomi dan sosial politik. Menurut Yakup (2019), kegiatan pariwisata sejalan dengan pertumbuhan ekonomi karena dapat meningkatkan pendapatan devisa dan membuka lowongan kerja. Selain itu, pariwisata juga berperan dalam aspek sosial politik karena mampu menumbuhkan rasa cinta tanah air serta persatuan dan kesatuan bangsa (Abdillah, 2016).

Provinsi Nusa Tenggara Barat terdiri dari dua pulau besar yaitu Pulau Lombok dan Pulau Sumbawa dan ratusan pulau kecil sehingga memiliki garis pantai yang cukup besar. Beberapa diantaranya menjadi destinasi wisata yang banyak dikunjungi wisatawan, sedangkan sebagian lainnya belum banyak dikunjungi wisatawan. Salah satu lokasi pantai yang belum banyak diketahui wisatawan lokal maupun mancanegara adalah Pantai Napak Tilas. Pantai ini berada dalam administrasi Desa Lembar Selatan, Kabupaten Lombok Barat. Pantai ini memiliki pemandangan yang unik yang tidak terdapat pada objek wisata lain yaitu pantai yang nemiliki ombak tenang dan dilintasi kapal-kapal besar. Karena ombaknya yang tenang, maka tidak berbahaya bagi pengunjung untuk berenang atau sekedar bermain air dipinggir pantai. Namun, kebersihan lingkungan pantai ini belum cukup bersih dan terawat, kondisi aksesibilitas yang tersedia kurang baik, dan objek wisata belum banyak dikembangkan dan dipublikasikan.

Menurut Ferdinandus \& Suryasih (2014), bahwa pengembangan destinasi wisata adalah tindakan yang dapat menyebabkan suatu lingkungan menjadi lebih baik dan meningkatkan daya tarik wisata. Berdasarkan hal tersebut, maka diperlukan kegiatan pengembangan Pantai Napak Tilas untuk mengatasi permasalahan-permasalahan yang dihadapi saat ini. Oleh sebab itu, kelompok KKN Desa Lembar Selatan mengangkat masalah tersebut sebagai tema KKN.

\section{METODE KEGIATAN}

Kegiatan ini dilakukan melalui program Kuliah Kerja Nyata (KKN) selama 30 hari pada bulan Juni - Juli di Desa Lembar Selatan, Kabupaten Lombok Barat. Kegiatan yang dilakukan meliputi survei lokasi, penataan dan pengembangan destinasi wisata. Pengumpulan data dan informasi mengenai potensi Desa Lembar Selatan dilakukan melalui dua cara yaitu studi literatur dan survei lapangan. Studi literatur dilakukan untuk memperoleh data sekunder yang berasal dari peta administrasi, data demografi, dan data infrastruktur Desa Lembar Selatan. Survei lapangan dilakukan melalui observasi lapangan dan wawancara yang dilakukan menghasilkan informasi mengenai kondisi fisik objek wisata, fasilitas yang ada di objek wisata, dan aksesibilitas menuju lokasi wisata dengan melalukan pengamatan langsung dilapangan. Hasil survei dituangkan dalam bentuk program kerja KKN. Program Kerja ini merupakan tindakan aksi dari hasil identifikasi masalah. Program kerja tersebut adalah bersih pantai dan penyuluhan sampah, pembuatan sarana pendukung dan promosi wisata.

\section{HASIL DAN PEMBAHASAN}

\section{Kondisi Umum Desa Lembar Selatan}

Desa Lembar Selatan memiliki luas wilayah $\pm 43.335 \mathrm{~m}^{2}$ dimana sebagian besar wilayahnya merupakan wilayah pemukiman. Total luas wilayah pemukiman $150 \mathrm{~m}^{2}$ dengan jumlah KK 3.442, jumlah jiwa 10.723 yang terdiri dari 5.436 jenis kelamin laki-laki dan 5.287 perempuan (Anonim, 2021). 
Desa Lembar Selatan terdiri dari 11 dusun dengan jumlah penduduk sebesar 10.566 jiwa dan salah satu dari 10 desa di Kecamatan Lembar. Batas wilayah Desa Lembar Selatan sebelah utara berbatasan dengan Desa Lembar, sebelah timur dengan Desa Labuan Tereng, dan sebelah barat dengan Selat Lombok (Gambar 1).

Pantai Napak Tilas terletak di Desa Lembar Selatan, Kecamatan Lembar Kabupaten Lombok Barat. Pantai ini selain memiliki ombak yang tenang juga memiliki pemandangan yang unik yang tidak terdapat pada objek wisata lain karena dilintasi kapal-kapal besar, dan memliki pohon cemara yang rindang. Namun kondisi objek wisata saat ini mengalami kerusakan karena lokasi wisata yang tidak terbebas dari sampah. Fasilitas penunjang wisata sebagai pemenuhan kebutuhan dasar wisatawan masih kurang. Prasarana jalan menuju lokasi wisata sudah tersedia namun kondisinya kurang baik. Jembatan kayu yang merupakan satu-satunya akses untuk menuju pantai ini juga dalam kondisi yang kurang baik. Namun demikian, Pemerintah Desa sudah ada rencana untuk memperbaiki.

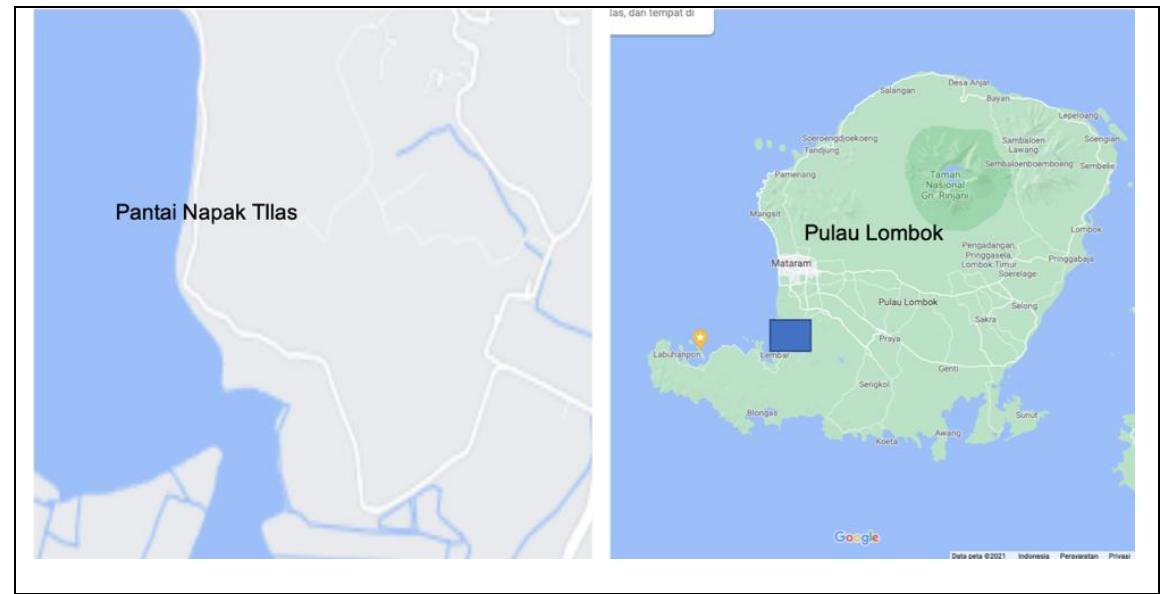

Gambar 1. Lokasi Desa Lembar Selatan dan Pantai Napak Tilas.

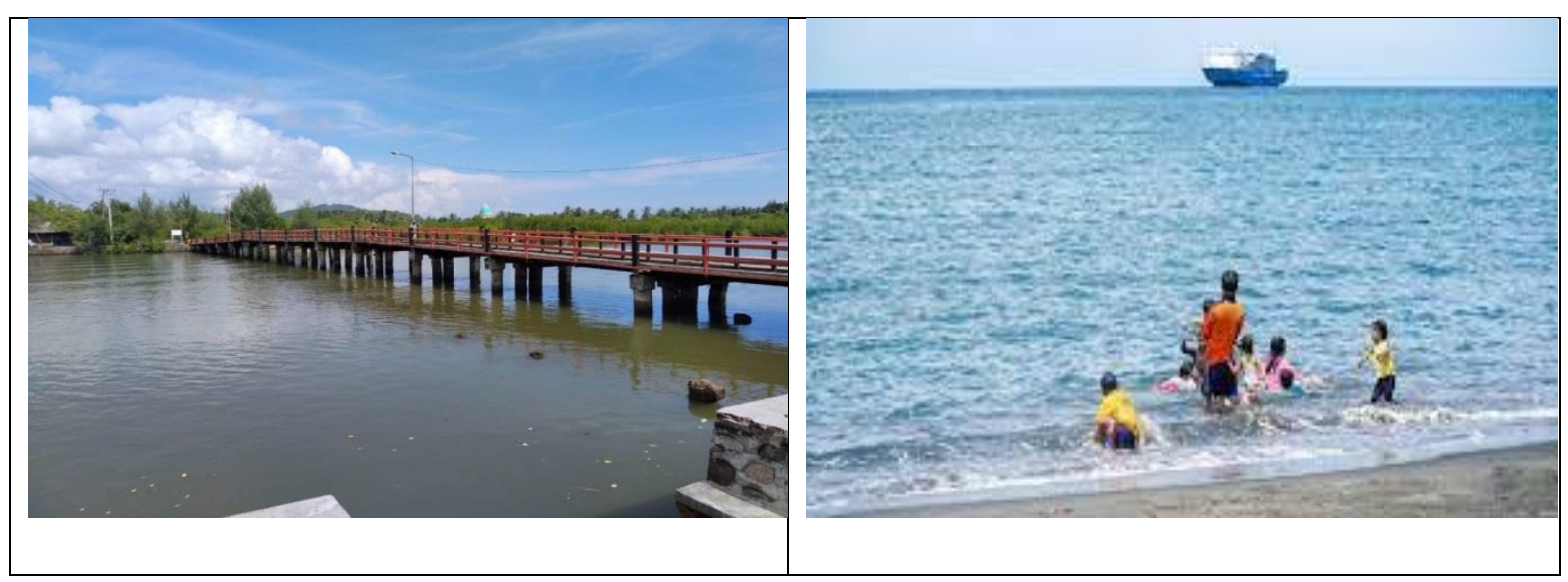

Gambar 2. Jembatan dan Suasana Pantai Napak Tilas

\section{Kegiatan Bersih Pantai dan Penyuluhan}

Kegiatan bersih pantai kami lakukan di Pantai Napak Tilas dengan berkoordinasi bersama Pokdarwis Desa Lembar Selatan. Kegiatan ini dilakukan setiap minggu selama waktu KKN untuk mensosialisasikan kepada pengunjung agar tetap menjaga lingkungan sekitar pantai dan tidak membuang sampah di sembarang tempat.

Pada kegiatan bersih pantai, jenis sampah yang terkumpul berupa sampah organik dan anorganik. Sampah organik adalah sampah yang berasal dari sisa mahluk hidup yang mudah terurai 
secara alami tanpa proses campur tangan manusia untuk dapat terurai seperti kayu, daun, sisa nasi dan sebagainya (Dinas Lingkungan Hidup, 2019). Jenis sampah ini mudah diuraikan mikroganisme, hanya saja jenis sampah ini akan menimbulkan bau kurang sedap jika tidak dikelola dengan baik. Jenis sampah organik yang banyak ditemukan di Pantai Napak Tilas adalah kayu, dimana adalah kayu tumbang yang terkena derasnya arus air bah sungai dan kayu dari sisa penebangan. Sampainya di Pantai Napak Tilas kayu-kayu dimanfaatkan untuk menambah bahan pembuatan spot foto atau tempat duduk. Kayu yang tidak bisa dimanfaatkan dibakar bersamaan dengan sampah lainnya seperti sampah dari buah pepohonan serta sampah dedaunan. Sedangkan Sampah Anorganik adalah sampah yang sudah tidak dipakai lagi dan sulit terurai seperti plastik, karet, kaleng dan sebagainya (Dinas Lingkungan Hidup, 2019). Sampah- sampah itu di Pantai Napak Tilas dimanfaatkan untuk membuat dan menambah nilai dari spot pantai seperti membuat spot foto bentuk Love dengan botol plastik dan membuat ayunan dengan karet bekas ban motor, selain dari itu sampah yang tidak bisa dimanfaatkan kemudian ditanam dan dibakar.

Berdasarkan asal sampah dapat dibagi menjadi dua yaitu sampah domestik yang dihasilkan dari kegiatan pariwisata dan sampah kiriman diduga berasal dari Sekotong yang terbawa oleh arus laut. Sampah kiriman sering terjadi pada sekitaran bulan Oktober sampai bulan Maret, lebih tepatnya di musim penghujan. Sejauh ini Masyarakat di Napak Tilas Masyarakat belum menemukan solusi untuk menangani kiriman sampah-sampah dengan jumlah banyak itu, masyarakat mengatasi sampah dengan cara memilah yang masih bisa digunakan, membakar dan menanam sampah. Namun demikian, pada waktu-waktu tertentu terdapat timbulan sampah di sekitar Pantai Napak Tilas.

Kesadaran masyarakat baik terhadap kebersihan lingkungan maupun dalam mencegah penularan covid-19 masih rendah. Masyarakat yang berjualan di Pantai Napak Tilas kurang mamiliki kesadaran akan pentingnya kebersihan lingkungan. Hal tersebut dapat dilihat mellaui keberadaan bak sampah yang hanya dimiliki beberapa warung sehingga sampah dibuang disembarang tempat.

Disamping itu, walaupun sudah ada imbauan tegas dari pemerintah daerah dan pihak-pihak terkait protokol Covid-19, nyatanya wisatawan dan pendatang lainnya seperti pedagang keliling belum sepenuhnya mengindahkan dan masih ada yang mengabaikan. Bahkan ada beberpa penjual di pantai tidak mengenakan masker. Namun, pengelola objek wisata Pantai Napak Tilas tetap berupaya memperketat penerapan protokol kesehatan. Didalam area pantai tampak setiap pedagang menyediakan tempat untuk mencuci tangan atau handsanitizer guna mencegah penularan Covid-19.

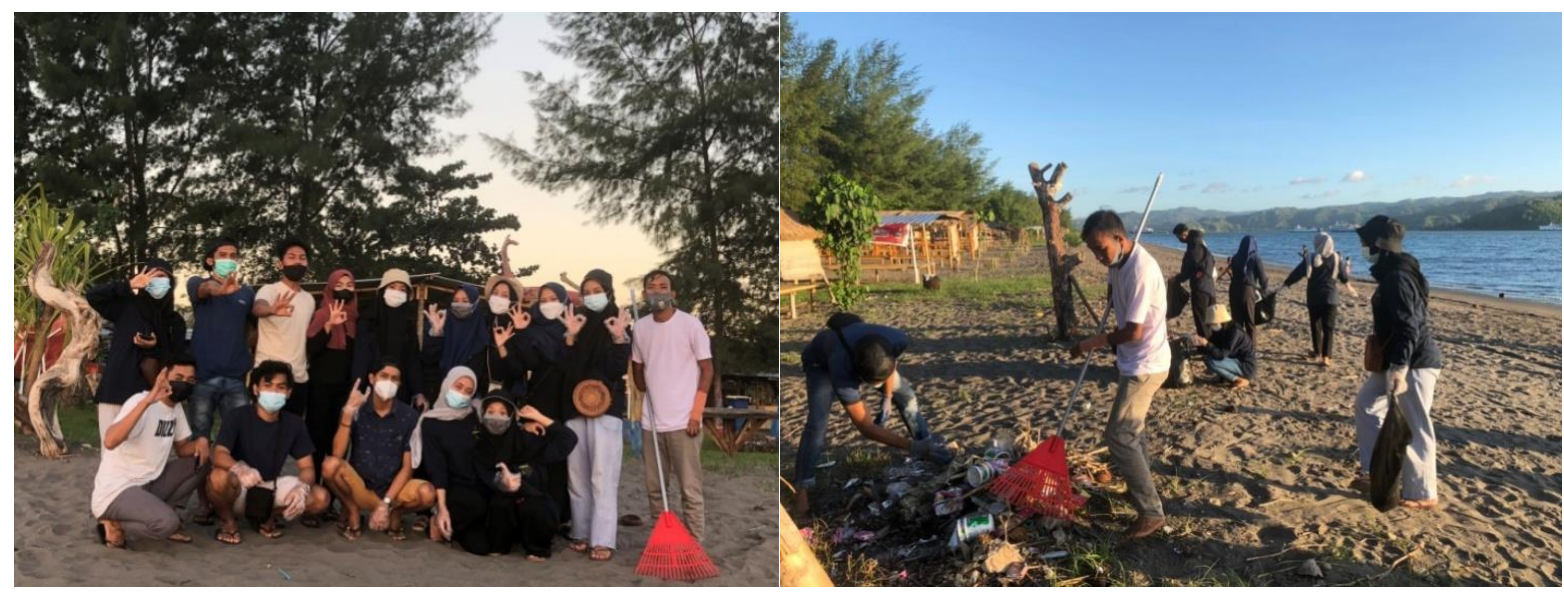

Gambar 3. Napak Tilas clean up bersama Pokdarwis

Penyuluhan sampah dilakukan kepada masyarakat yang memiliki warung di Pantai Napak Tilas. Hal tersebut bertujuan untuk memberikan informasi yang diharapkan mampu membuka kesadaran akan pentingnya pelestarian lingkungan. Kegiatan ini dilakukan dengan membagikan 
selebaran menggunakan strategi door to door yaitu mendatangi langsung warung-warung di Pantai Napak Tilas. Strategi tersebut digunakan karena kondisi pandemi yang tidak memperbolehkan adanya kerumunan. Namun karena waktu yang terbatas, kegiatan ini tidak dapat menjangkau semua masyarakat yang berjualan di Pantai Napak Tilas.

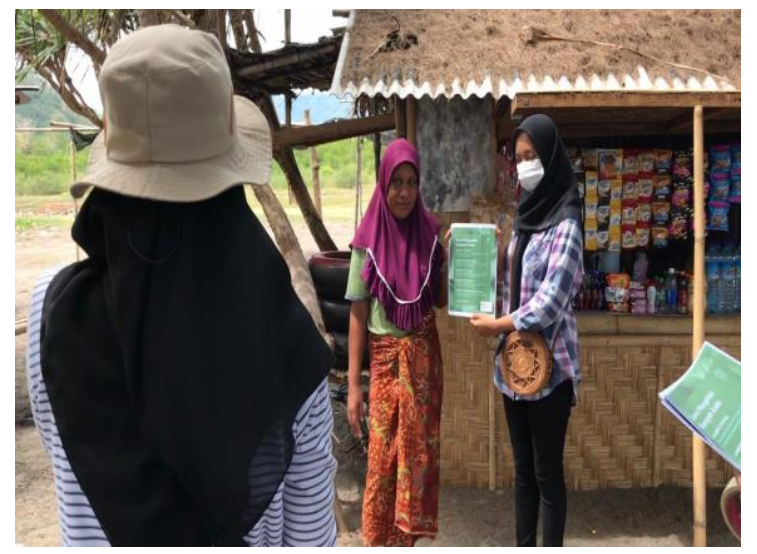

Gambar 4. Penyuluhan sampah kepada warung-warung di Pantai Napak Tilas

Berkaitan dengan terciptanya kawasan wisata pantai yang indah dan bersih kami membuat bak sampah untuk diletakkan pada beberapa spot di Pantai Napak Tilas. Hal tersebut dilakukan karena di Pantai Napak Tilas ketersediaan bak sampah masih kurang. Melalui sarana ini diharapkan mampu mengurangi jumlah sampah yang dibuang sembarangan di pantai. Bak sampah yang dibuat memiliki ukuran yang pas dan dapat dipindahkan. Namun karena jumlah yang sedikit maka belum efektif untuk mengurangi jumlah sampah sepenuhnya.

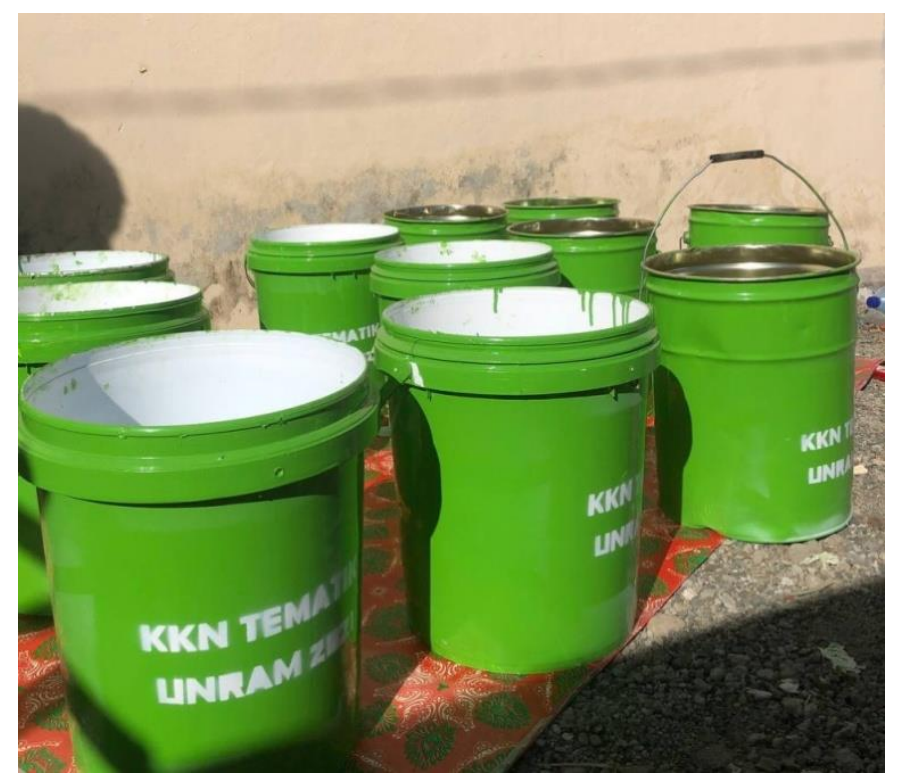

Gambar 5. Pembuatan bak sampah

\section{Pembuatan sarana pendukung}

Pembuatan plang penunjuk arah Pantai Napak Tilas dan pembuatan sarana berupa kursi untuk pengunjung pantai. Pembuatan plang penunjuk arah bertujuan untuk memberikan informasi mengenai lokasi Pantai Napak Tilas serta untuk memudahkan aksesibilitas wisatawan karena hanya Pantai Napak Tilas yang belum memiliki plang arah. Kelebihan plang kayu salah satunya yaitu ramah lingkungan. Namun, kayu rentan diserang oleh hama dan lemah dalam menghadapi perubahan cuaca. 
Selain itu, kami juga membuat sarana berupa kursi untuk pengunjung pantai. Kelebihan kursi kayu antara lain ramah lingkungan, dan sederhana. Namun, kursi yang terbuat dari kayu mudah lapuk dan digerogoti oleh rayap.

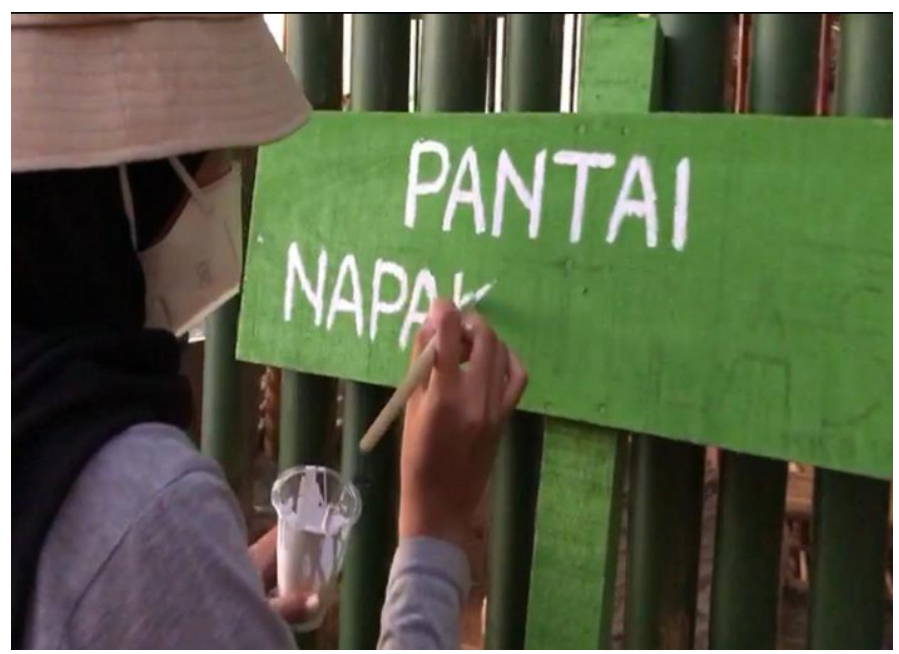

Gambar 6. Pembuatan papan penunjuk arah Pantai Napak Tilas

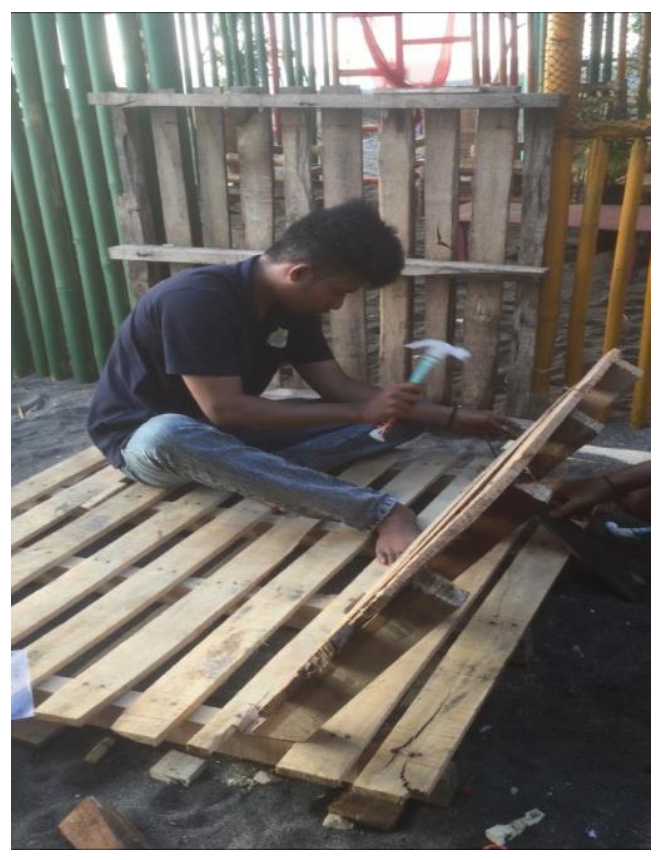

Gambar 7. Pembuatan kursi untuk pengunjung Pantai Napak Tilas

\section{Promosi Wisata}

Kegiatan terakhir yaitu promosi dimana promosi adalah upaya untuk memberitahukan atau menawarkan produk atau jasa dengan tujuan menarik calon konsumen untuk membeli atau mengkonsumsinya. Promosi destinasi wisata bertujuan untuk memperkenalkan kepada masyarakat luas mengenai potensi wisata yang dimiliki Pantai Napak Tilas. Promosi ini kami lakukan melalui media sosial Instagram @kkn_lembar. Konten-konten yang kami bagikan berupa foto dan video keindahan Pantai Napak Tilas serta menyebutkan lokasi pantai tersebut. Namun karena pengikut yang masih sedikit maka promosi yang dilakukan kurang efisien. 
Penggunaan media sosial untuk promosi sudah banyak dilakukan (Oktaviani \& Rustandi, 2018; Indika \& Jovita, 2017). Dalam kaitannya dengan promosi tempat wisata, menurut Pratama et al., (2021), bahwa wisatawan menentukan tujuan wisata berdasarkan dari citra tempat wisata yang banyak disukai oleh pengunjung. Oleh sebab itu, penggunakan media sosial Instagram untuk mempromosikan wisata Pantai Napak Tilas menjadi hal yang tepat karena melalui hal tersebut informasi mengenai daerah wisata dapat diakses dengan mudah. Semakin banyak informasi mengenai keindahan Pantai Napak Tilas yang disebarkan melalui Instagram akan berdampak pada peningkatan jumlah kunjungan.

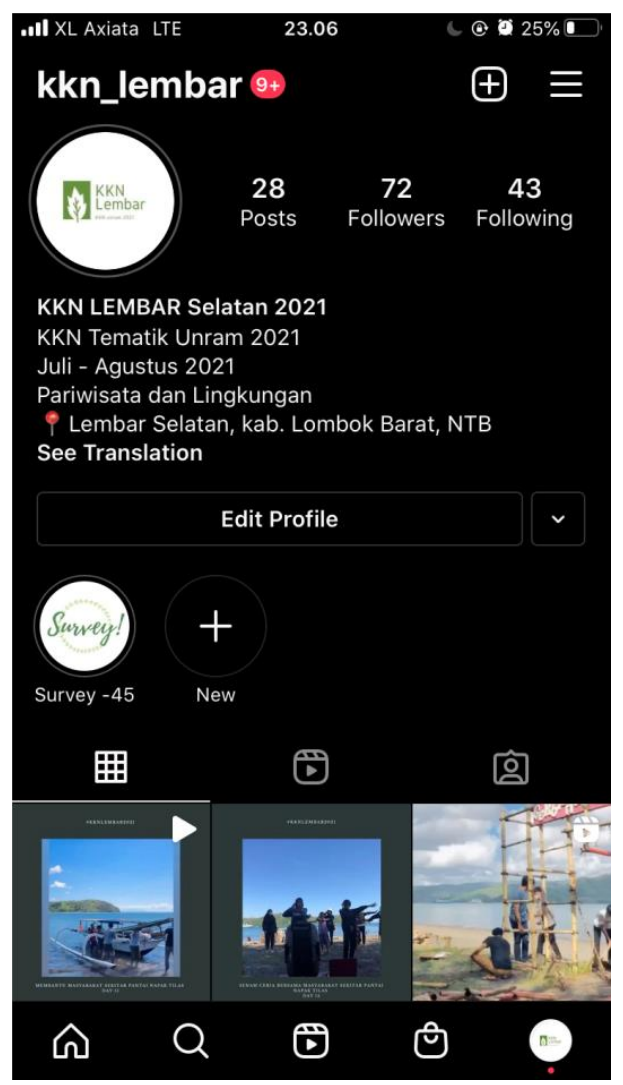

Gambar 8. Tampilan Instagram KKN Lembar

\section{KESIMPULAN DAN SARAN}

Berdasarkan kegiatan yang telah dilakukan dapat disimpulkan bahwa seluruh program yang direncanakan untuk mengembangkan Pantai Napak Tilas seperti kegiatan bersih pantai, pembuatan sarana pendukung dan promosi melalui media sosial dapat terlaksana dengan baik berkat kerjasama antara mahasiswa, pemerintah desa, dan masyarakat. Semua kegiatan yang dilaksanakan mengikuti protokol Covid-19. Namun demikian, masalah sampah kiriman menjadi tantangan besar terbesar dalam pengelolaan Pantai Napak Tilas sehingga diperlukan kerjasama lebih lanjut antara masyarakat, pemerintah desa, dan pihak swasta untuk menanganinya.

\section{UCAPAN TERIMAKASIH}

Kegiatan ini dilakukan dalam rangka Kuliah Kerja Nyata di Periode Juni 2021. Untuk itu kami mengucapkan terimakasih kepada Ketua dan seluruh staf Lembaga Penelitian dan Pengabdian Kepada Masyarakat (LPPM) Universitas Mataram dan Koordinator Layanan KKN Universitas Mataram yang telah memfasilitasi pembekalan dan pengaturan KKN. Ucapan terimakasih juga kami sampaikan 
kepada Kepala Desa, Kepala Dusun, POKDARWIS dan seluruh perangkat Desa Lembar Selatan serta seluruh masyarakat yang telah membantu dan berpartisipasi dalam kegiatan ini.

\section{DAFTAR PUSTAKA}

Abdillah, J. (2016). Pengembangan Wisata Bahari di Pesisir Pantai Teluk Lampung. Jurnal Destinasi Kepariwisataan Indonesia, 1(1), $45-66$.

Anonim. (2021). Desa Lembar Selatan. http://lembarselatan.desa.id/demografi

Dinas Lingkungan Hidup. (2019). Pengertian Dan Pengelolaan Sampah Organik Dan Anorganik. https://dlh.bulelengkab.go.id/informasi/detail/artikel/pengertian-dan-pengelolaan-sampahorganik-dan-anorganik-13

Ferdinandus, A. M., \& Suryasih, I. A. (2014). Studi Pengembangan Wisata Bahari Untuk Meningkatkan Kunjungan Wisatawan Di Pantai Natsepa Kota Ambon Provinsi Maluku. Jurnal Destinasi Pariwisata, 2(2), 1-12.

Indika, D. R., \& Jovita, C. (2017). Media Sosial Instagram Sebagai Sarana Promosi Untuk Meningkatkan Minat Beli Konsumen. Jurnal Bisnis Terapan, 1(1), 25-32. https://doi.org/https://doi.org/10.24123/jbt.v1i01.296

Oktaviani, F., \& Rustandi, D. (2018). Implementasi Digital Marketing dalam Membangun Brand Awareness. Jurnal Profesi Humas, 3(1), 1-20.

Pratama, R. G. I., Athar, H. S., \& Furkan, L. M. (2021). Observasi keputusan Berkunjung Wisatawan pada kawasan Taman Wisata Gunung Tunak berdasarkan Pengaruh Citra Destinasi, Produk Wisata Dan Ewom". (daring). Jurnal Magister Manajemen, 10(1), 33-42. https://doi.org/http://dx.doi.org/10.29303/jmm.v10i1A.620

Yakup, A. P. (2019). Pengaruh Sektor Pariwisata Terhadap Pertumbuhan Ekonomi di Indonesia. Universitas Airlangga, Surabaya. 